\section{'AZTECA', PRIMER HÍBRIDO DE PAPAYA PARA EL TRÓPICO DE MÉXICO}

\section{'AZTEC', THE FIRST PAPAYA HYBRID FOR THE TROPICAL CONDITIONS OF MÉXICO}

\author{
Felipe Mirafuentes Hernández ${ }^{*}$ y \\ Alfonso Azpeitia Morales
}

\footnotetext{
${ }^{1}$ Campo Experimental Huimanguillo, Instituto Nacional de Investigaciones Forestales, Agrícolas y Pecuarias. Km 1 Carretera HuimanguilloCárdenas, Apdo. Postal No. 17, 86400. Tel 01(917)375-03-96.

*Autor para correspondencia (mirafuentes.felipe@inifap.gob.mx)
}

La papaya (Carica papaya L.) es una fruta tropical muy apetecible por su suave y agradable sabor, aunado a sus propiedades nutritivas y digestivas. El cultivo es atractivo para el agricultor, por su rentabilidad, periodo corto entre siembra y cosecha, y alto rendimiento por hectárea (Arango y Roman, 2000). Las plantaciones están asociadas a productores de gran escala con visión empresarial y para los asociados con otros productores, pues se necesitan cerca de $\$ 100$ mil pesos ( $\$ 10$ mil dólares americanos) para el establecimiento de una hectárea. La rentabilidad de este cultivo es alta, pues por cada peso invertido se recuperan \$2.74 pesos (Plan Rector del Sistema Producto Papaya, 2003), lo que genera mayores ingresos que cacao (Theobroma cacao L.), cocotero (Cocos nucife$r a$ L.) y naranja (Citrus sinencis L. Osbek). En México se cultivan 20400 ha, con una producción de 952194 t la cual se exporta $31 \%$ (FAO, 2006). Se cultiva principalmente en los Estados de Veracruz (8 189 ha), Chiapas (1 809 ha), Michoacán (1 550 ha), Tabasco (1 200 ha), Guerrero (1 077 ha), Yucatán (1 028 ha), Oaxaca (804 ha) y Nayarit (608 ha) (Plan Rector del Sistema Producto Papaya, 2003).

Sin embargo, la planta es seriamente afectada por plagas y enfermedades. La principal enfermedad viral es el enchinamiento o mancha grasienta de la papaya, conocida comúnmente como "virosis", producida por el virus de la mancha anular de la papaya (PRSV), ampliamente disperso en las plantaciones, y el más perjudicial en México y en la mayoría de los países productores (Manshardt, 1992). Otro virus que afecta al papayo es el del mosaico de la papaya (PapMV), reportado por primera vez en México en el año de 2001 (Noa-Carrazana y SilvaRosales, 2001).
El mejoramiento genético representa la vía más duradera para controlar las enfermedades virales en el papayo; en varios países se han producido variedades tolerantes mediante cruzas entre papayos (Lima et al., 2002; Vegas et al., 2002), híbridos entre esta especie con otras silvestres, y variedades genéticamente modificadas (Tennnant et al., 2005). En México, la falta de semilla mejorada de papayo, y la susceptibilidad a plagas y enfermedades de las variedades e híbridos introducidos motivó desarrollar al primer híbrido de este frutal, que se ha denominado 'Azteca'. Este híbrido se adapta a las condiciones ambientales tropicales de México con alta humedad ambiental (60 a $80 \%$ ), temperaturas promedio de 23 a 26 ${ }^{\circ} \mathrm{C}$, y reúne las características de calidad comercial que demanda el mercado, como fruto intermedio (de 2 a 3 $\mathrm{kg}$ ), aromático, mayor contenido de sólidos solubles, consistencia de la pulpa, mayor resistencia al transporte, y además tolera al PRSV y PapMV.

Los progenitores del híbrido provienen de una colecta de genotipos iniciada en 1993 en el Estado de Tabasco, México; estos genotipos fueron autofecundados durante cinco ciclos para homogenizar sus caracteres, y posteriormente los mejores individuos se seleccionaron por selección masal con base en características fenotípicas como: altura de planta, tamaño de hoja, número de entrenudos, número de flores, número y tamaño de frutos, altura del primer fruto, presencia de síntomas asociados con virosis (enchinamiento del follaje), principalmente; y comparadas con variedades comerciales como 'Sunrise', 'Maradol' y 'Tainung' entre otras.

De esta evaluación surgieron los progenitores denominados $\mathrm{J}$ y $\mathrm{B}$. El progenitor $\mathrm{J}$ es una planta de porte vigoroso, hojas de color verde oscuro con textura gruesa, frutos de 2 a $3 \mathrm{~kg}$ de peso fresco; altura media de $3.5 \mathrm{~m}$; fruto de color naranja con semillas café oscuro; y con tolerancia a virosis (sin síntomas de virosis en follaje). El progenitor B es una planta de dosel mediano (2.5 a $3 \mathrm{~m})$, con frutos de 0.5 a $1 \mathrm{~kg}$ de peso fresco, hojas de color verde claro, fruto de color naranja y pulpa suave con semillas café claro, y susceptible a virosis. El progenitor $\mathbf{J}$ se utilizó como planta macho y el progenitor B como planta hembra; la cruza simple F1 se denominó híbrido 'Azteca', cuyas características principales son: resistencia a virosis y vigor provenientes del progenitor masculino; y suavidad y aroma de la pulpa, así como el grosor del epicarpio del fruto del progenitor femenino. En estudios moleculares de tejido foliar para determinar la presencia de PRSV y PapMV en cinco genotipos ('Azteca', 'Sunrise', 'Tabasco', 'Maradol' y 'Tainung'), 'Azteca' fue el más resistente pues no presentó PapMV y PRSV en los tres tipos de pruebas (RT-PCR, Elisa, y Northern); solamente con la prueba RT-PCR (reacción en cadena de la 
polimerasa en tiempo real) dio positivo para el PRSV en una planta que presentó síntomas asociados con la virosis. En evaluaciones en campo realizadas en seis localidades (Revolución Mexicana y Tapachula, Chiapas; Cárdenas, Huimanguillo, Balancán y Tacotalpa, Tabasco) durante los ciclos Primavera-Verano y Otoño-Invierno, destacó su alto vigor y rendimiento en comparación con 'Maradol'.

El híbrido 'Azteca' (Figura 1) tiene una altura promedio de $2.17 \mathrm{~m}$, longitud de hoja de $1.54 \mathrm{~m}$, ancho de hoja de $0.74 \mathrm{~m}$, altura del primer fruto de $70 \mathrm{~cm}$, peso del fruto de 2 a $2.8 \mathrm{~kg}$ y $12.44{ }^{\circ}$ Brix. El híbrido 'Azteca' produjo un promedio de 38.5 frutos/planta $v s$. 33.9 de la variedad 'Maradol', y la superó en 35.5 t ha $^{-1}$ (127.5 vs. $90 \mathrm{t}$ ha $\left.^{-1}\right)$; además, el fruto de 'Azteca' es más dulce que el de 'Maradol' (12.44 vs. $10.48{ }^{\circ}$ Brix); y en evaluaciones de campo ha demostrado mayor tolerancia a los virus asociados con la papaya (incidencias promedio de $21 \%$ vs. 52 $\%$ de 'Maradol'), y mayor tolerancia a infestaciones de ácaros (3 colonias vs. 15) (Mirafuentes y Azpeitia, 2006a).

Actualmente se encuentra en evaluación un lote comercial de cinco meses de establecida en el Estado de Veracruz (principal productor), donde ha mostrando buena adaptabilidad, mayor número de frutos que el testigo 'Maradol' y no presenta síntomas asociados con virosis, por lo que es muy factible establecerla con éxito en los estados de la región sur-sureste de México.

La siembra de semilla de este primer híbrido de papayo desarrollado en México (registro provisional otorgado en el año 2007 por el Servicio Nacional de Inspección y Certificación de Semillas, Núm. 1946-PAY-002290507/C) permitirá elevar la producción de este cultivo ya que sus frutos poseen las características que el mercado nacional e internacional demandan. Este año (2008) se encuentra establecido un lote comercial de producción de semillas que podrá cubrir las necesidades de este insumo en una cuarta parte (300 ha) de las plantaciones establecidas en Tabasco, y con posibilidades de incrementar la producción de semilla de acuerdo con la demanda del mercado estatal y regional.
Además, se dispone de información técnica por parte de los obtentores de este híbrido, respecto al manejo del cultivo en particular (Mirafuentes y Azpeitia, 2006b), que garantice un alto rendimiento al productor de la fruta de papaya en México.

\section{AGRADECIMIENTOS}

A la fundación Produce Tabasco A. C por el financiamiento parcial recibido a través del proyecto "Desarrollo de genotipos de papaya tolerantes a acarosis/virosis en las condiciones ambientales de Tabasco".

\section{BIBLIOGRAFÍA}

Arango W L V, H A C Roman (2000) Aspectos agroeconómicos. In: El Cultivo de la Papaya en los Llanos Orientales de Colombia. L. V. Arango W (ed). Corporación Colombiana de Investigación Agropecuaria. pp:8-12.

FAO (2006) http://faostat.fao.org/ (20 de junio de 2008).

Lima R, M Sousa, G (Pio-Ribeiro, R Lima (2002) Sequences of the coat protein gene from Brazilian isolates of papaya ringspot virus. Fitopat. Bras. 27:74-180.

Manshardt R M (1992) Papaya. In: Biotechnology of Perennial Fruit Crops. F A Hammerschlag, F A Litz, R E Litz (eds.) CAB International, Wallingford, UK. pp:489-511.

Mirafuentes H F, M A Azpeitia ( 2006a) A z t e c a: primer híbrido de papaya tolerante a "virosis" para consumo nacional y exportación. In: XIX Reunión Científica Forestal y Agropecuaria 2006. U A Báez R (ed). Villahermosa, Tabasco. 16-17. Nov. Tabasco, México. pp:295-299.

Mirafuentes H F, M A Azpeitia (2006b) A z t e c a: primer híbrido de papayo mexicano tolerante a virosis para consumo nacional $\mathrm{y}$ exportación. In: Innovaciones Tecnológicas 2006. INIFAP (ed). pp:55-56.

Noa-Carrazana J C, L Silva-Rosales (2001) First report of a mexican isolate of Papaya mosaic virus in Papaya (Carica papaya) and Pumpkin (Cucurbita pepo). Plant Dis. 85:558.

Plan Rector del Sistema Producto Papaya (2003). Secretaria de Agricultura, Ganadería, Desarrollo Rural, Pesca y Alimentación, México. 72 p.

Tennant P, M H Ahmad, D Gonsalves (2005) Field resistance of coat protein transgenic papaya to papaya ringspot virus in Jamaica. Plant Dis. 89:841-847.

Vegas A T, G R Tovar, P I Mújica, C N Hernández, A González, S Yeh (2002) Obtención y selección de cepas atenuadas del virus de la mancha anillada de la lechosa mediante mutagénesis in vitro en Venezuela. Fitopat. Ven. 15:33-38. 


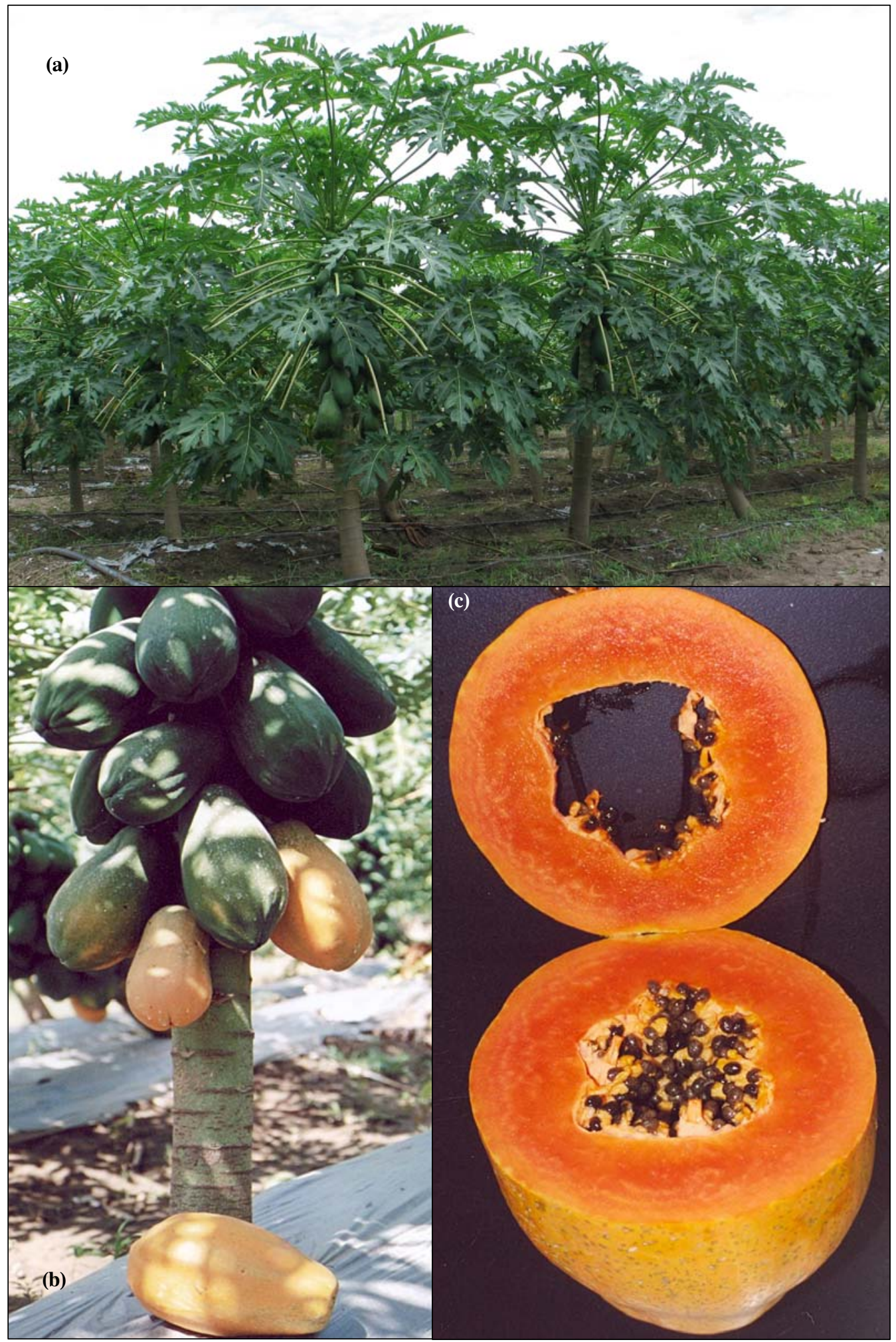

Figura 1. Nuevo híbrido de papaya, 'Azteca'. a) Plantación semicomercial en Huimanguillo, Tabasco; b) Planta adulta de 12 meses en plena producción; c) Fruto maduro. 